\title{
Milk composition, milk fatty acid profile, digestion, and ruminal fermentation in dairy cows fed whole flaxseed and calcium salts of flaxseed oil ${ }^{1}$
}

\author{
C. Côrtes, ${ }^{*}$ D. C. da Silva-Kazama,† R. Kazama,† N. Gagnon, ${ }^{*}$ C. Benchaar, ${ }^{*}$ G. T. D. Santos, $†$ L. M. Zeoula,† \\ and H. V. Petit*2 \\ *Dairy and Swine Research and Development Centre, Agriculture and Agri-Food Canada, Stn. Lennoxville, Sherbrooke, QC J1M 1Z3, Canada \\ †Departamento de Zootecnia, Universidade Estadual de Maringa, Maringa, PR, Brazil
}

\begin{abstract}
Four ruminally lactating Holstein cows averaging 602 $\pm 25 \mathrm{~kg}$ of body weight and $64 \pm 6 \mathrm{~d}$ in milk at the beginning of the experiment were randomly assigned to a $4 \times 4$ Latin square design to determine the effects of feeding whole flaxseed and calcium salts of flaxseed oil on dry matter intake, digestibility, ruminal fermentation, milk production and composition, and milk fatty acid profile. The treatments were a control with no flaxseed products $(\mathrm{CON})$ or a diet (on a dry matter basis) of $4.2 \%$ whole flaxseed (FLA), $1.9 \%$ calcium salts of flaxseed oil (SAL), or 2.3\% whole flaxseed and $0.8 \%$ calcium salts of flaxseed oil (MIX). The 4 isonitrogenous and isoenergetic diets were fed for ad libitum intake. Experimental periods consisted of $21 \mathrm{~d}$ of diet adaptation and $7 \mathrm{~d}$ of data collection and sampling. Dry matter intake, digestibility, milk production, and milk concentrations of protein, lactose, urea $\mathrm{N}$, and total solids did not differ among treatments. Ruminal $\mathrm{pH}$ was reduced for cows fed the CON diet compared with those fed the SAL diet. Propionate proportion was higher in ruminal fluid of cows fed CON than in that of those fed SAL, and cows fed the SAL and CON diets had ruminal propionate concentrations similar to those of cows fed the FLA and MIX diets. Butyrate concentration was numerically higher for cows fed the SAL diet compared with those fed the FLA diet. Milk fat concentration was lower for cows fed SAL than for those fed CON, and there was no difference between cows fed CON and those fed FLA and MIX. Milk yields of protein, fat, lactose, and total solids were similar among treatments. Concentrations of cis-9 18:1 and of intermediates of ruminal biohydrogenation of fatty acids such as trans-9 18:1 were higher in milk fat of cows fed SAL and MIX than for those fed the CON diet. Concentration of rumenic acid (cis-9, trans-11 18:2)
\end{abstract}

\footnotetext{
Received November 12, 2009.

Accepted March 13, 2010.

${ }^{1}$ Contribution number 1031 from the Dairy and Swine Research and Development Centre.

${ }^{2}$ Corresponding author: helene.petit@agr.gc.ca
}

in milk fat was increased by $63 \%$ when feeding SAL compared with FLA. Concentration of $\alpha$-linolenic acid was higher in milk fat of cows fed SAL and MIX than in milk of cows fed CON (75 and 61\%, respectively), whereas there was no difference between FLA and CON. Flaxseed products (FLA, SAL, and MIX diets) decreased the n- 6 to n-3 fatty acid ratio in milk fat. Results confirm that flax products supplying 0.7 to $1.4 \%$ supplemental fat in the diet can slightly improve the nutritive value of milk fat for better human health.

Key words: flaxseed, calcium salts, dairy cow, milk fatty acid

\section{INTRODUCTION}

Polyunsaturated fatty acids (PUFA) such as the n-3 family are not synthesized by humans, and consumers are increasingly aware of the potential health benefits of these fatty acids (FA). As a result, there is growing interest to manipulate dairy cow diets to increase concentrations of PUFA in milk fat. However, this is a difficult challenge because ruminal microorganisms modify the dietary FA profile through isomerization and biohydrogenation of unsaturated FA (Harvatine and Allen, 2005).

Milk fat composition can be modulated through feeding strategies. For example, feeding flaxseed increases the proportions of n- 3 FA and cis-9, trans-11 18:2 conjugated linoleic acid (CLA) in milk fat (Glasser et al., 2008) although the proportion of linolenic acid (cis-9, cis-12, cis-15 18:3) in milk fat of cows supplemented with n-3 FA from whole flaxseed (Petit, 2002) does not exceed $1 \%$ of total FA. However, when a source of n-3 FA such as flaxseed oil, which is rich in linolenic acid, was infused in the small intestine to bypass the rumen, concentrations of n-3 FA reached $14 \%$ of total FA in milk fat (Petit et al., 2002). Therefore, the potential exists to increase milk fat concentration of n-3 FA when linolenic acid is protected against ruminal biohydrogenation. One method of protection has been through the use of calcium salts (Ca-salts) of FA that were developed to reduce the negative effects of fat on ruminal fermentation (Ferlay et al., 1992). The propor- 
tions of n-3 FA were increased from 1.20 to $2.25 \mathrm{~g} / 100$ $\mathrm{g}$ of FA in milk fat of dairy cows fed 0 to $5.4 \%$ Ca-salts of flaxseed oil in the DM, although protection against ruminal biohydrogenation of PUFA led to no increase in CLA proportion (Brzóska, 2006). Because n-3 FA and some CLA such as cis-9, trans-11 18:2 could have beneficial effects on human health (Wright et al., 1998; Belury, 2002), there are advantages to increase both of these FA in milk fat. Flaxseed may help to increase both cis-9, trans-11 18:2 and n-3 FA in milk fat, as previously reported by Glasser et al. (2008), although Ca-salts of flaxseed oil may lead to greater increases in $\mathrm{n}-3 \mathrm{FA}$ proportion in milk fat than whole flaxseed because of putative protection against ruminal biohydrogenation, suggesting that a mixture of both may result in the best milk FA profile. However, there is no known comparison between whole flaxseed and Ca-salts of flaxseed oil as feed ingredients for dairy cow diets. Therefore, the objective of the experiment was to compare diets providing similar fat amounts supplied by a natural feed ingredient (whole flaxseed), a protected oil (Ca-salts of flaxseed oil), and a combination of both on digestion, ruminal fermentation parameters, production, and composition of milk.

\section{MATERIALS AND METHODS}

\section{Cows and Diets}

Four lactating primiparous Holstein cows fitted with ruminal cannulas $(10 \mathrm{~cm}$, Bar Diamond Inc., Parma, ID) were used in a $4 \times 4$ Latin square design with four 28-d periods. Cows were fed a TMR (Table 1) with no flaxseed products (control, CON), or diets of (DM basis) $4.2 \%$ whole unprocessed flaxseed (FLA), $1.9 \%$ Ca-salts of flaxseed oil (SAL), or $2.3 \%$ whole unprocessed flaxseed and $0.8 \%$ Ca-salts of flaxseed oil (MIX). The Ca-salts supplement (81\% FA, DM basis) was supplied by Virtus Nutrition Inc. (Corcoran, CA). The 4 TMR were isonitrogenous and isoenergetic and were formulated to meet or exceed nutrient requirements for cows that average $615 \mathrm{~kg}$ of BW and produce $37 \mathrm{~kg} / \mathrm{d}$ of milk with $3.9 \%$ of fat (NRC, 2001). The cows were kept in individual stalls and had free access to water. The cows averaged $64 \pm 6$ DIM at the start of the experiment with an average BW of $602 \pm 25$ $\mathrm{kg}$ and an average BCS of $2.9 \pm 0.23$ (5-point scale; Edmonson et al., 1989). Diets were offered in equal amounts twice daily at 0830 and $1530 \mathrm{~h}$ for ad libitum intake (10\% refusals) and cows were milked twice daily at 0800 and $1900 \mathrm{~h}$. Yield of 4\% FCM was calculated according to the equation of Tyrrell and Reid (1965). Body weight was determined at the beginning and the end of each experimental period after the a.m. milking on 3 consecutive days. National guidelines for the care and use of animals were followed as recommended by the Canadian Council on Animal Care (1993) and all experimental procedures were approved by the local Animal Care Committee.

\section{Experimental Procedures}

Each experimental period consisted of $21 \mathrm{~d}$ of adaptation to the diets and $6 \mathrm{~d}$ of total data collection and sampling. Feed intake and milk yield were measured daily throughout the experiment. On d 20, cows were fitted with harnesses and tubes allowing the total collection of feces and urine separately. From d 21 to 27, feces were collected from a rubber mat placed behind the animals and stored in plastic containers. Daily feces were weighed and mixed thoroughly and a $2 \%$ subsample was taken and stored at $-20^{\circ} \mathrm{C}$ for subsequent freeze drying. Total daily urine was collected in stainless steel containers via a Gooch tube (BF Goodrich Co., Kitchener, ON, Canada) attached to the cow with a nylon netting covered with neoprene (Spall Bowan Ltd., Guelph, ON, Canada) affixed to the vulva. Urine was acidified daily with $100 \mathrm{~mL}$ of $10 \mathrm{~N} \mathrm{H}_{2} \mathrm{SO}_{4}$. A $1 \%$ daily subsample was taken and kept frozen until analysis. Samples of the 4 TMR were taken daily during the digestibility week (d 21 to 28 ) and pooled within period for each cow. All samples were frozen at $-20^{\circ} \mathrm{C}$ for subsequent drying at $55^{\circ} \mathrm{C}$. Milk samples were obtained from each cow for 12 consecutive milkings during the digestibility trial and pooled on a yield basis after freezing and thawing. One sample without preservative was used for analyses of milk fat and FA profile. Another sample was stored at $+4^{\circ} \mathrm{C}$ with a preservative (bronopol-B2) until analyzed for protein, urea $\mathrm{N}$, lactose, and total solids. On d 28 , a 200-mL sample of ruminal fluid was collected from each of 5 different sites within the rumen (anterior dorsal, anterior ventral, medium ventral, posterior dorsal, and posterior ventral locations) before feeding $(0 \mathrm{~h})$ and at $1,2,4$, and $6 \mathrm{~h}$ after the a.m. feeding. All samples were pooled on an hourly basis and strained through 2 layers of cheesecloth to separate the liquid and solid fractions; $\mathrm{pH}$ (Accumet pH meter, Fisher Scientific, Montreal, QC, Canada) was measured immediately. One sample of filtered ruminal fluid was frozen at $-20^{\circ} \mathrm{C}$ for further analyses of FA profile. Another sample of filtered ruminal fluid was acidified to $\mathrm{pH} 2$ with $50 \% \mathrm{H}_{2} \mathrm{SO}_{4}$ and frozen at $-20^{\circ} \mathrm{C}$ for later determination of VFA and ammonia $\mathrm{N}$ concentrations.

\section{Chemical Analysis}

Dry matter of the diets and feces were determined in a forced-air oven according to AOAC method 934.01 
Table 1. Ingredient, chemical composition, and fatty acid profile of the TMR containing no flaxseed products $(\mathrm{CON})$, whole flaxseed (FLA), calcium salts of flaxseed oil (SAL), or a mixture of whole flaxseed and calcium salts of flaxseed oil $(\mathrm{MIX})^{1}$

\begin{tabular}{|c|c|c|c|c|c|}
\hline \multirow[b]{2}{*}{ Item } & \multicolumn{4}{|c|}{ Treatment } & \multirow[b]{2}{*}{$\mathrm{SE}$} \\
\hline & $\mathrm{CON}$ & FLA & SAL & MIX & \\
\hline \multicolumn{6}{|l|}{ Ingredient, $\%$ of $\mathrm{DM}$} \\
\hline Grass silage & 27.7 & 27.7 & 30.8 & 28.7 & \\
\hline Corn silage & 27.8 & 27.7 & 30.8 & 28.7 & \\
\hline Cracked corn grain & 21.6 & 19.7 & 14.4 & 18.0 & \\
\hline Ground barley & 7.3 & 7.2 & 7.3 & 7.3 & \\
\hline Soybean meal & 7.5 & 5.9 & 7.5 & 7.1 & \\
\hline Calcium salts of flaxseed oil $^{2}$ & 0 & 0 & 1.9 & 0.8 & \\
\hline Whole flaxseed ${ }^{3}$ & 0 & 4.2 & 0 & 2.3 & \\
\hline Top supplement ${ }^{4}$ & 4.6 & 4.2 & 4.6 & 4.2 & \\
\hline Calcium carbonate & 0.6 & 0.6 & 0.3 & 0.3 & \\
\hline Mineral $^{5}$ & 2.9 & 2.9 & 2.5 & 2.5 & \\
\hline \multicolumn{6}{|l|}{ Chemical analysis } \\
\hline DM, \% & 46.0 & 45.6 & 43.3 & 44.0 & 1.6 \\
\hline $\mathrm{CP}, \%$ of $\mathrm{DM}$ & 17.4 & 17.0 & 17.2 & 17.1 & 0.2 \\
\hline Ether extract, \% of DM & 2.18 & 3.62 & 2.85 & 3.18 & 0.14 \\
\hline $\mathrm{NDF}, \%$ of DM & 28.2 & 29.7 & 31.6 & 30.2 & 0.9 \\
\hline $\mathrm{ADF}, \%$ of $\mathrm{DM}$ & 22.1 & 23.2 & 25.6 & 23.7 & 0.8 \\
\hline NFC, $\%$ of $\mathrm{DM}^{6}$ & 45.3 & 42.8 & 40.9 & 42.6 & 0.8 \\
\hline $\mathrm{NE}_{\mathrm{L}}, \mathrm{Mcal} / \mathrm{kg}$ of $\mathrm{DM}^{7}$ & 1.63 & 1.62 & 1.65 & 1.64 & \\
\hline \multicolumn{6}{|l|}{ Fatty acids, $\%$ of total fatty acids } \\
\hline $4: 0$ & 0.32 & 0.29 & 0.26 & 0.29 & 0.03 \\
\hline $6: 0$ & 0.43 & 0.34 & 0.37 & 0.37 & 0.03 \\
\hline $12: 0$ & 0.86 & 0.75 & 0.67 & 0.73 & 0.08 \\
\hline Cis-11 12:1 & 0.56 & 0.49 & 0.48 & 0.48 & 0.05 \\
\hline Cis-12 13:1 & 0.17 & 0.00 & 0.07 & 0.13 & 0.07 \\
\hline 14:0 & 0.79 & 0.67 & 0.61 & 0.67 & 0.08 \\
\hline $15: 0$ & 0.28 & 0.25 & 0.23 & 0.24 & 0.03 \\
\hline $16: 0$ & 17.2 & 14.2 & 14.1 & 14.0 & 0.3 \\
\hline Cis-9 16:1 & 0.57 & 0.52 & 0.49 & 0.49 & 0.06 \\
\hline $17: 0$ & 0.39 & 0.31 & 0.29 & 0.32 & 0.04 \\
\hline $18: 0$ & 2.11 & 2.52 & 2.65 & 2.49 & 0.12 \\
\hline Cis-9 18:1 & 18.6 & 18.6 & 17.4 & 17.8 & 0.7 \\
\hline Cis-11 18:1 & 1.14 & 1.12 & 1.10 & 1.10 & 0.02 \\
\hline Cis-9, cis-12 18:2 & 47.1 & 37.5 & 36.4 & 37.0 & 0.5 \\
\hline Cis-9, cis-12, cis-15 18:3 & 7.81 & 21.8 & 23.5 & 22.6 & 0.7 \\
\hline $20: 0$ & 0.58 & 0.22 & 0.32 & 0.33 & 0.08 \\
\hline $22: 0$ & 0.44 & 0.20 & 0.33 & 0.35 & 0.08 \\
\hline $24: 0$ & 0.35 & 0.27 & 0.30 & 0.30 & 0.02 \\
\hline$n-6^{8}: n-3^{9}$ & 6.13 & 1.72 & 1.57 & 1.65 & 0.24 \\
\hline
\end{tabular}

${ }^{1}$ Least squares means with pooled standard error (SE).

${ }^{2}$ Contained (\% of total fatty acids): $0.06 \% 14: 0,5.68 \% 16: 0,2.91 \% 18: 0,19.4 \%$ cis-9 18:1, $0.87 \%$ cis-11 $18: 1$, $17.2 \%$ cis-9, cis-12 18:2, 53.4\% cis-9, cis-12, cis-15 18:3, 0.22\% 20:0, 0.05\% 22:0, 0.02\% cis-11, cis-14, cis-17 $20: 3$, and $0.18 \% 24: 0$.

${ }^{3}$ Contained (\% of total fatty acids): $0.09 \% 14: 0,5.81 \% 16: 0,3.15 \%$ 18:0, 0.18\% trans-9 18:1, 0.21\% trans- 11 $18: 1,0.15 \%$ cis-6 18:1, $16.9 \%$ cis-9 18:1, 0.80\% cis-11 18:1, $17.9 \%$ cis-9, cis-12 18:2, 54.5\% cis-9, cis-12, cis-15 18:3, 0.21\% 20:0, 0.05\% 22:0, 0.03\% cis-11, cis-14, cis-17 20:3, and 0.08\% 24:0.

${ }^{4}$ Contained (\%, as-is basis): $20 \%$ of canola meal, $30 \%$ of corn gluten meal, $20 \%$ of soybean meal, and $30 \%$ of brewer's corn.

${ }^{5}$ Contained (\%, as-is basis): $9.02 \% \mathrm{Ca}, 4.90 \% \mathrm{P}, 4.89 \% \mathrm{Mg}, 1.76 \% \mathrm{~S}, 14 \% \mathrm{Na}, 1.43 \% \mathrm{~K}, 2,068 \mathrm{mg} / \mathrm{kg}$ of $\mathrm{Fe}$, $2,718 \mathrm{mg} / \mathrm{kg}$ of Zn, $447 \mathrm{mg} / \mathrm{kg}$ of Cu, $1,814 \mathrm{mg}$ of Mn, $69 \mathrm{mg} / \mathrm{kg}$ of I, $7 \mathrm{mg} / \mathrm{kg}$ of Co, $20 \mathrm{mg} / \mathrm{kg}$ of Se, 452,000 $\mathrm{IU} / \mathrm{kg}$ of vitamin $\mathrm{A}, 58,000 \mathrm{IU} / \mathrm{kg}$ of vitamin $\mathrm{D}_{3}$, and $2,692 \mathrm{IU} / \mathrm{kg}$ of vitamin $\mathrm{E}$.

${ }^{6}$ Calculated by difference: $\mathrm{NFC}=100-(\mathrm{CP}+$ ether extract + ash $+\mathrm{NDF})$.

${ }^{7}$ Calculated using published values of feed ingredients (NRC, 2001).

${ }^{8}$ cis-9, cis-12 18:2.

${ }^{9}$ cis-9, cis-12, cis-15 18:3.

(AOAC, 1990). Total mixed dried diets and freezedried feces were ground to pass a $1-\mathrm{mm}$ screen in a Wiley mill before analyses of total $\mathrm{N}$, ether extract, ADF, and NDF. Total N content of TMR and feces was determined by thermal conductivity (Leco model FP-428 Nitrogen Determinator, Leco, St. Joseph, MI), and $\mathrm{CP}$ was calculated as $\mathrm{N} \times 6.25$. The concentration of NDF in TMR and feces was determined as described 
by Van Soest et al. (1991) with the inclusion of heatstable $\alpha$-amylase and with and without the use of sodium sulfite, respectively. The ADF content in TMR and feces was determined according to AOAC (1990; method 973.18). The NDF and ADF procedures were adapted for use in an Ankom ${ }^{200}$ Fiber Analyzer (Ankom Technology Corp., Fairport, NY). Ether extraction of diets and feces was conducted according to method no. 7.060 (AOAC, 1990). The concentration of $\mathrm{N}$ in acidified urine samples was determined by micro-Kjeldahl analysis (AOAC, 1990; method 960.52). Concentrations of ammonia $\mathrm{N}$ and VFA in ruminal fluid were analyzed, respectively, using the indophenol-blue method (Novozamsky et al., 1974) and an HPLC Waters Alliance 2695 system (Waters, Milford, MA) fitted with a flame ionization detector. Milk fat concentration was determined by the method of Röse-Gottlieb (AOAC, 1990). Protein, lactose, total solids, and urea $\mathrm{N}$ concentrations in milk samples were analyzed by infrared spectrophotometry (System 4000 Milkoscan, Foss Electric, Hillerød, Denmark) following method 972.16 of AOAC (1990). Milk fat was extracted and FA were methylated according to the methods described by Chouinard et al. (1997), and in situ transesterification was performed on diets according to Park and Goins (1994). Fat in ruminal liquor samples was extracted and FA were methylated by the one-step procedure of Sukhija and Palmquist (1988) using hexane instead of benzene.

Individual FA were identified by comparison of gas chromatography peaks with peaks of known standards (GLC-463, Nu-Chek Prep Inc., Elysian, MN). Individual conjugated linoleic acid standards were used to identify trans-10, cis-12 18:2 (\#MT1254, Matreya LLC, Pleasant Gap, PA) and cis-9, trans-11 18:2 (\#MT1255, Matreya LLC). Fatty acid methyl esters were separated on an Agilent 6890 GLC fitted with an Agilent autosampler (model \#7683, Agilent injector, Agilent Ltd., Mississauga, ON, Canada) and a flameionization detector. Agilent Chemstation Rev. B.01.03 (204) software was used for chromatogram integration and analysis. Samples were introduced onto a 100-m Varian (Toronto, ON, Canada) CP Sil 88 column (part number CP7489) via $1-\mu \mathrm{L}$ split injections with a split ratio $75: 1$. The temperature program was as follows: level $1,72^{\circ} \mathrm{C}$ held for $0.5 \mathrm{~min}$; level 2,72 to $196^{\circ} \mathrm{C}$ at $2.4^{\circ} \mathrm{C} / \mathrm{min}$ increments, then held for $1 \mathrm{~min}$; level 3, 196 to $215^{\circ} \mathrm{C}$ in $1.7^{\circ} \mathrm{C} / \mathrm{min}$ increments, then held for $32 \mathrm{~min}$. Injector temperature was set at $230^{\circ} \mathrm{C}$, and the detector was set at $235^{\circ} \mathrm{C}$. Column head pressure was set at 30 psi. A 4-mm i.d. split injection liner (Mandel, Guelph, ON, Canada) was used for all injections. Gas flow rates were helium (carrier) $1.0 \mathrm{~mL} / \mathrm{min}$, helium (make up) $34.5 \mathrm{~mL} / \mathrm{min}$, compressed air $450 \mathrm{~mL} / \mathrm{min}$, and hydrogen $40 \mathrm{~mL} / \mathrm{min}$.
Individual FA in diets and ruminal fluid were identified as described above for milk but with some modifications of the temperature program as follows: level 1 , $80^{\circ} \mathrm{C}$ held for $1.0 \mathrm{~min}$; level 2,80 to $215^{\circ} \mathrm{C}$ in $1.55^{\circ} \mathrm{C} / \mathrm{min}$ increments, then held for $12 \mathrm{~min}$. Injector temperature was set at $230^{\circ} \mathrm{C}$, and the detector was set at $300^{\circ} \mathrm{C}$. Column head pressure was set at 17.6 psi. A 4-mm i.d. split injection liner (Mandel, Guelph, ON, Canada) was used for all injections. Gas flow rates were as follows: hydrogen (carrier) $1.0 \mathrm{~mL} / \mathrm{min}$, nitrogen (make up) 44 $\mathrm{mL} / \mathrm{min}$, compressed air $450 \mathrm{~mL} / \mathrm{min}$, and hydrogen 40 $\mathrm{mL} / \mathrm{min}$. Peaks were routinely identified by comparison of retention times with FA methyl esters standards (GLC 463, Nu-Chek Prep Inc.). The trans-18:1 isomers were identified by order of elution as described by Precht et al. (2001). Separations of all FA were obtained with a single chromatographic run. Although the use of both hydrogen and helium as carrier gas gave similar results for determination of FA proportions, helium provided better stability for FA separation than hydrogen. Therefore, it was decided to use helium as carrier gas for further experiments.

\section{Statistical Analysis}

Data on fecal and urine output, feed intake, and milk production were averaged over the $6 \mathrm{~d}$ of the digestibility week and subjected to ANOVA. All data from the experiment were analyzed as a $4 \times 4$ Latin square design balanced for residual effect using the GLM procedure (SAS Institute, 2000) with the following model:

$$
\mathrm{Y}_{\mathrm{ijkl}}=\mu+\mathrm{C}_{\mathrm{j}}+\mathrm{P}_{\mathrm{k}}+\mathrm{T}_{\mathrm{l}}+\mathrm{e}_{\mathrm{ijkl}} \text {, }
$$

where $\mathrm{Y}_{\mathrm{ijkl}}=$ the dependent variable, $\mu$ = overall mean, $\mathrm{C}_{\mathrm{j}}=$ random effect of cow $(\mathrm{j}=1$ to 4$), \mathrm{P}_{\mathrm{k}}=$ fixed effect of period ( $\mathrm{k}=1$ to 4$), \mathrm{T}_{1}$ = fixed effect of treatment (1 $=\mathrm{CON}, \mathrm{FLA}, \mathrm{SAL}, \mathrm{MIX})$, and $\mathrm{e}_{\mathrm{ijkl}}=$ random residual error. Data on ruminal fermentation characteristics $(\mathrm{pH}, \mathrm{VFA}$, ammonia $\mathrm{N})$ were analyzed as repeated measurements using PROC MIXED, and compound symmetry was used as the covariance structure. Significance was declared at $P \leq 0.05$ and a trend at $0.05<$ $P \leq 0.10$, unless otherwise stated. When a significant $F$-test was detected, multiples comparisons were done using a Tukey's adjustment for the probability.

\section{RESULTS AND DISCUSSION}

\section{Feed Composition}

The chemical composition of the TMR (Table 1) was generally similar among diets. As expected, ether extract concentration was lower for the CON diet than 
for the FLA, SAL, and MIX diets. Although the FLA, SAL, and MIX diets were formulated to have similar ether extract concentrations, the increase in dietary ether extract concentration due to lipid supplement (CON diet vs. other treatments) was 1.4, 0.7, and 1.0\% for FLA, SAL, and MIX, respectively (Table 1). The greatest difference between dietary ether extract content due to lipid supplements was between FLA and SAL, which must be taken into account to interpret differences between these 2 treatments on the measured parameters. Dietary concentration of NFC was higher for CON than for SAL (45.3 vs. $40.9 \%$ of the DM, respectively). Substitution of corn grain by Ca-salts of flaxseed oil in the SAL diet may decrease NFC concentration. Indeed, the greatest difference in corn grain concentration was observed between diets $\mathrm{CON}$ and SAL (21.6 vs. $14.4 \%$ of the DM, respectively).

As expected, proportions of FA were similar among the FLA, SAL, and MIX diets, and they were different from those in the CON diet. Concentrations of 16:0 and cis-9, cis-12 18:2 and the n- 6 to n-3 FA ratio were higher for the CON diet than for the FLA, SAL, and MIX diets (Table 1). On the other hand, the concentration of cis-9, cis-12, cis-15 18:3 was lower in the CON diet than in the 3 other treatments. Flaxseed and flaxseed oil are rich sources of cis-9, cis-12, cis-15 18:3 (Mustafa et al., 2002; Petit, 2002), thus increasing the relative proportion of linolenic acid in the FLA, SAL, and MIX diets.

\section{Feed Intake, BW, Diet Digestibility, and N Balance}

There was no difference $(P>0.05)$ among treatments for DMI, expressed in kilograms per day or as a percentage of $\mathrm{BW}$, initial $\mathrm{BW}$, final $\mathrm{BW}, \mathrm{BW}$ change, diet digestibility, or $\mathrm{N}$ balance (Table 2). The proportions of whole flaxseed added to the dietary DM of the FLA and MIX diets were 4.2 and $2.3 \%$, respectively. In general, untreated whole flaxseed is readily accepted by dairy cows, and feeding up to $15 \%$ of the total DM as flaxseed has no effect on DMI of cows in the mid (Secchiari et al., 2003) and early stages of lactation (Petit, 2002). Similarly, feeding diets of $10 \%$ whole flaxseed in the DM had no effect on digestibility (Petit, 2002) although lower digestibility of $\mathrm{DM}, \mathrm{OM}, \mathrm{NDF}$, and ADF has been reported for cows fed $12 \%$ (DM basis) whole flaxseed in the diet (Martin et al., 2008). Discrepancies between experiments may result from differences in diet composition or in the number of animals used in each study. Recent results (Doreau et al., 2009) reported similar ruminal digestion when dry cows were supplemented with $7.5 \%$ rolled flaxseed, $7.5 \%$ extruded flaxseed, or $2.6 \%$ flaxseed oil. Allen (2000) investigated several studies $(\mathrm{n}=28)$ involving the supply of Ca-salts of palm oil in the diets of dairy cows and concluded that for every $1 \%$ of added Ca-salts of palm oil over the control diet, a depression of $2.5 \%$ in DMI occurred. In the present experiment, the addition of Ca-salts was $1.9 \%$ of the DM, which may not have been high enough to depress DMI and digestibility as observed in previous studies carried out with Ca-salts of palm oil. Moreover, Ca-salts of flax oil and Ca-salts of palm oil may have different effects on feed intake and digestion.

\section{Ruminal Fermentation Characteristics}

There was no interaction $(P>0.10)$ between sampling time and treatment for ruminal $\mathrm{pH}$ and ammonia N and VFA concentrations (data not shown). Therefore, only mean values are presented (Table 3 ). Ruminal $\mathrm{pH}$ was significantly reduced for cows fed the CON diet compared with those fed the SAL diet (Table 3). However, ruminal $\mathrm{pH}$ of cows fed the SAL and CON diets was similar to that of cows fed the FLA and MIX diets (Table 3). Propionate proportion was significantly higher in ruminal fluid of cows fed CON than in ruminal fluid of those fed SAL, and cows fed the SAL and CON diets had ruminal propionate concentrations similar to those of cows fed the FLA and MIX diets. Lower ruminal $\mathrm{pH}$ and higher propionate concentration for cows fed CON compared with those fed SAL may partly be a result of a greater amount of readily fermentable carbohydrates (e.g., corn grain) in the CON diet than in the SAL diet (Table 1). Ruminal concentrations of ammonia N, total VFA, and molar proportions of acetate, isobutyrate, valerate, isovalerate, and lactic acid were not affected by treatments (Table 3). Ruminal concentration of butyrate tended $(P=0.08)$ to differ among diets. Butyrate concentration was numerically higher for cows fed the SAL diet compared with those fed the FLA diet. The acetate to propionate ratio tended $(P=0.06)$ to differ among diets and it was numerically higher for cows fed SAL and MIX compared with those fed CON (Table 3).

Results of the present experiment are consistent with the data of Enjalbert et al. (1997) who observed no effect of Ca-salts of palm oil and rapeseed oil fed at $4 \%$ of DM on total and individual proportions of ruminal VFA. On the other hand, feeding $12.5 \%$ whole flaxseed in the DM decreased the molar proportion of acetate and increased that of propionate, resulting in lower acetate to propionate ratio (Gonthier et al., 2004). Similarly, heifers fed $10 \%$ (DM basis) Ca-salts of vegetable oil rich in 18:2 n-6 had low acetate to propionate ratio in ruminal fluid (Chalupa et al., 1986). In the present study, the amounts of oil supplied by the flaxseed products were lower compared with amounts used in other studies (Chalupa et al., 1986; Gonthier 
Table 2. Intake, initial and final BW, digestibility, and $\mathrm{N}$ output of Holstein cows fed diets containing no flaxseed product (CON), whole flaxseed (FLA), calcium salts of flaxseed oil (SAL), or a mixture of whole flaxseed and calcium salts of flaxseed oil (MIX) ${ }^{1}$

\begin{tabular}{|c|c|c|c|c|c|c|}
\hline \multirow[b]{2}{*}{ Item } & \multicolumn{4}{|c|}{ Treatment } & \multirow[b]{2}{*}{$\mathrm{SE}$} & \multirow[b]{2}{*}{$P$-value } \\
\hline & $\mathrm{CON}$ & FLA & SAL & MIX & & \\
\hline DMI, kg/d & 22.0 & 22.7 & 21.5 & 21.5 & 0.4 & 0.32 \\
\hline DMI, $\%$ of BW & 3.62 & 3.71 & 3.53 & 3.51 & 0.07 & 0.38 \\
\hline \multicolumn{7}{|l|}{$\mathrm{BW}, \mathrm{kg}$} \\
\hline Initial & 600 & 600 & 602 & 604 & 3 & 0.82 \\
\hline Final & 618 & 624 & 619 & 619 & 1 & 0.15 \\
\hline Change, kg/d & 0.62 & 0.84 & 0.60 & 0.52 & 0.14 & 0.51 \\
\hline \multicolumn{7}{|l|}{ Digestibility, \% } \\
\hline $\mathrm{DM}$ & 64.6 & 64.1 & 65.5 & 65.2 & 0.6 & 0.47 \\
\hline $\mathrm{CP}$ & 65.3 & 64.9 & 68.2 & 66.5 & 1.0 & 0.29 \\
\hline $\mathrm{ADF}$ & 50.8 & 49.6 & 52.8 & 52.1 & 2.4 & 0.81 \\
\hline NDF & 42.0 & 45.8 & 45.6 & 46.5 & 1.3 & 0.26 \\
\hline NFC & 79.7 & 76.8 & 79.7 & 78.8 & 1.0 & 0.33 \\
\hline Ether extract & 80.7 & 79.6 & 84.6 & 79.7 & 1.4 & 0.21 \\
\hline \multicolumn{7}{|l|}{$\mathrm{N}$ balance, $\mathrm{g} / \mathrm{d}$} \\
\hline $\mathrm{N}$ intake & 612 & 621 & 595 & 587 & 9 & 0.19 \\
\hline $\mathrm{N}$ in feces & 212 & 217 & 189 & 196 & 6 & 0.14 \\
\hline $\mathrm{N}$ in urine & 211 & 218 & 223 & 242 & 15 & 0.56 \\
\hline $\mathrm{N}$ in milk & 178 & 183 & 184 & 190 & 8 & 0.79 \\
\hline $\mathrm{N}$ retained & 11 & 3 & -1 & -41 & 15 & 0.24 \\
\hline
\end{tabular}

${ }^{1}$ Least squares means with pooled standard error (SE).

et al., 2004), which may explain the lack of effects of fat supplementation on ruminal fermentation characteristics. Moreover, discrepancies between studies could be due in part to differences in diet composition, the amount of Ca-salts added to the diet, or the oil FA profile. For example, results from a recent in vitro study (Maia et al., 2007) reported that although sensitivity differs among species, growth of ruminal bacteria could be affected by the type of PUFA, which could directly influence ruminal fermentation.

\section{FA Profile of Ruminal Fluid}

The concentration of 4:0 was lower $(P=0.05)$ in the rumen of cows fed FLA compared with those fed CON, and cows fed the SAL and MIX diets had 4:0 concentrations similar to those of cows fed CON and FLA diets (Table 4). Feeding FLA and MIX compared with CON significantly decreased the concentration of 5:0 in ruminal fluid, and cows fed the SAL and MIX diets had 5:0 concentrations similar to those fed the CON and

Table 3. Ruminal fermentation characteristics of Holstein cows fed diets containing no flaxseed product $(\mathrm{CON})$, whole flaxseed (FLA), calcium salts of flaxseed oil (SAL), or a mixture of whole flaxseed and calcium salts of flaxseed oil $(\mathrm{MIX})^{1}$

\begin{tabular}{lcccccc}
\hline & \multicolumn{7}{c}{ Treatment } & & \\
\cline { 2 - 5 } Item & CON & FLA & SAL & MIX & SE & $P$-value \\
\hline $\mathrm{pH}$ & $6.15^{\mathrm{b}}$ & $6.22^{\text {ab }}$ & $6.32^{\mathrm{a}}$ & $6.29^{\mathrm{ab}}$ & 0.04 & 0.05 \\
Ammonia N, mg/100 mL & 14.3 & 14.2 & 15.3 & 14.7 & 0.9 & 0.82 \\
Total VFA, $\mathrm{m} M$ & 107 & 108 & 110 & 104 & 4 & 0.74 \\
VFA, mol/100 mol & 60.9 & 62.5 & 62.8 & 63.6 & 0.7 & 0.12 \\
Acetate (A) & $22.6^{\mathrm{a}}$ & $21.6^{\mathrm{ab}}$ & $19.9^{\mathrm{b}}$ & $20.1^{\text {ab }}$ & 0.6 & 0.05 \\
Propionate (P) & 12.1 & 11.9 & 12.8 & 12.3 & 0.2 & 0.08 \\
Butyrate (B) & 0.75 & 0.74 & 0.77 & 0.83 & 0.03 & 0.20 \\
Isobutyrate & 1.39 & 1.29 & 1.31 & 1.32 & 0.06 & 0.62 \\
Valerate & 1.65 & 1.68 & 1.50 & 1.57 & 0.07 & 0.36 \\
Isovalerate & 0.61 & 0.28 & 0.92 & 0.25 & 0.28 & 0.35 \\
Lactic & 2.78 & 2.94 & 3.18 & 3.19 & 0.10 & 0.06 \\
A:P & 0.31 & 0.29 & 0.26 & 0.27 & 0.01 & 0.06 \\
P/(A+B) & & & & & & \\
\hline
\end{tabular}

${ }^{\mathrm{a}, \mathrm{b}}$ Means within a row with no common superscript differ $(P \leq 0.05)$.

${ }^{1}$ Least squares means with pooled standard error (SE). 
Table 4. Fatty acid profile in ruminal fluid (\% of total fatty acids) of Holstein cows fed diets containing no flaxseed product $(\mathrm{CON})$, whole flaxseed (FLA), calcium salts of flaxseed oil (SAL) or a mixture of whole flaxseed and calcium salts of flaxseed oil (MIX)

\begin{tabular}{|c|c|c|c|c|c|c|}
\hline \multirow[b]{2}{*}{ Fatty acid,$^{2} \%$ of total fatty acids } & \multicolumn{4}{|c|}{ Treatment } & \multirow[b]{2}{*}{$\mathrm{SE}$} & \multirow[b]{2}{*}{$P$-value } \\
\hline & $\mathrm{CON}$ & FLA & SAL & MIX & & \\
\hline $4: 0$ & $39.5^{\mathrm{a}}$ & $34.0^{\mathrm{b}}$ & $38.6^{\mathrm{ab}}$ & $35.6^{\mathrm{ab}}$ & 0.85 & 0.05 \\
\hline $5: 0$ & $6.68^{\mathrm{a}}$ & $5.54^{\mathrm{b}}$ & $5.79^{\mathrm{ab}}$ & $5.60^{\mathrm{b}}$ & 0.14 & 0.03 \\
\hline $6: 0$ & 2.71 & 2.50 & 2.65 & 2.93 & 0.37 & 0.86 \\
\hline $7: 0$ & 0.39 & 0.42 & 0.36 & 0.41 & 0.06 & 0.87 \\
\hline $14: 0$ & 0.70 & 0.56 & 0.27 & 0.28 & 0.16 & 0.34 \\
\hline $15: 0$ & 0.65 & 0.62 & 0.48 & 0.57 & 0.04 & 0.21 \\
\hline $16: 0$ & 11.4 & 11.3 & 10.7 & 11.2 & 0.19 & 0.29 \\
\hline $17: 0$ & 0.25 & 0.26 & 0.13 & 0.17 & 0.05 & 0.43 \\
\hline $18: 0$ & $25.8^{\mathrm{b}}$ & $32.1^{\mathrm{a}}$ & $26.7^{\mathrm{b}}$ & $30.3^{\mathrm{a}}$ & 0.48 & 0.01 \\
\hline Trans-9 18:1 & 0.15 & 0.24 & 0.33 & 0.22 & 0.06 & 0.45 \\
\hline Trans-11 18:1 & $2.36^{\mathrm{b}}$ & $2.42^{\mathrm{b}}$ & $3.17^{\mathrm{a}}$ & $2.77^{\mathrm{ab}}$ & 0.07 & 0.01 \\
\hline Trans- $13+1418: 1+$ cis $-6+818: 1$ & $0.44^{\mathrm{b}}$ & $0.68^{\mathrm{ab}}$ & $0.86^{\mathrm{a}}$ & $0.78^{\mathrm{a}}$ & 0.04 & 0.02 \\
\hline Cis-9 18:1 & $3.07^{\mathrm{b}}$ & $3.67^{\mathrm{ab}}$ & $4.42^{\mathrm{a}}$ & $3.98^{\mathrm{ab}}$ & 0.16 & 0.03 \\
\hline Cis-11 18:1 & 1.09 & 1.21 & 1.31 & 1.25 & 0.07 & 0.35 \\
\hline Trans-9, trans-12 18:2 & 0.16 & 0.24 & 0.13 & 0.12 & 0.04 & 0.34 \\
\hline Cis-9, cis-12 18:2 & $3.39^{\mathrm{a}}$ & $2.84^{\mathrm{b}}$ & $2.63^{\mathrm{b}}$ & $2.59^{\mathrm{b}}$ & 0.05 & 0.01 \\
\hline Cis-9, trans-11 18:2 & 0.40 & 0.38 & 0.39 & 0.31 & 0.02 & 0.19 \\
\hline Cis-9, cis-12, cis-15 18:3 & 0.15 & 0.34 & 0.13 & 0.14 & 0.08 & 0.39 \\
\hline $20: 0$ & 0.22 & 0.22 & 0.24 & 0.28 & 0.12 & 0.98 \\
\hline $22: 0$ & 0.18 & 0.23 & 0.25 & 0.24 & 0.06 & 0.82 \\
\hline 24.0 & 0.22 & 0.26 & 0.28 & 0.28 & 0.07 & 0.92 \\
\hline MUFA & $7.24^{\mathrm{b}}$ & $8.39^{\mathrm{ab}}$ & $10.07^{\mathrm{a}}$ & $8.97^{\mathrm{ab}}$ & 0.29 & 0.02 \\
\hline PUFA & $4.08^{\mathrm{a}}$ & $3.78^{\mathrm{ab}}$ & $3.26^{\mathrm{ab}}$ & $3.15^{\mathrm{b}}$ & 0.14 & 0.05 \\
\hline SFA & 88.8 & 88.0 & 86.7 & 87.9 & 0.42 & 0.13 \\
\hline SCFA & 49.5 & 42.7 & 47.6 & 44.7 & 1.33 & 0.11 \\
\hline MCFA & 12.8 & 12.6 & 11.5 & 12.0 & 0.32 & 0.15 \\
\hline LCFA & $37.5^{\mathrm{b}}$ & $44.6^{\mathrm{a}}$ & $40.8^{\mathrm{ab}}$ & $43.2^{\mathrm{ab}}$ & 1.02 & 0.05 \\
\hline
\end{tabular}

${ }^{\mathrm{a}, \mathrm{b}}$ Means within a row with no common superscript differ $(P \leq 0.05)$.

${ }^{1}$ Least squares means with pooled standard error (SE).

${ }^{2} \mathrm{MUFA}=$ monounsaturated fatty acids; PUFA = polyunsaturated fatty acids; SFA = saturated fatty acids; SCFA $=$ short-chain fatty acids; MCFA = medium-chain fatty acids; LCFA = long-chain fatty acids.

FLA diets. Concentrations of 6:0, 7:0, 14:0, 15:0, 16:0, and 17:0 in ruminal fluid were similar among treatments. Feeding FLA and MIX significantly increased the concentration of 18:0 in ruminal fluid compared with CON and SAL.

Although the concentration of stearic acid (18:0) in the diets was low, and concentrations of unsaturated 18-carbon FA, such as cis-9 18:1, cis-9, cis-12 18:2, and cis-9, cis-12, cis-15 18:3 were high (Table 1 ), stearic acid (18:0) was the major long-chain FA in ruminal fluid on all diets. This is consistent with the great dissociation of Ca-salts of unsaturated FA in the rumen (Sukhija and Palmquist, 1990) and only partial protection of Ca-salts of unsaturated FA against biohydrogenation (Ferlay et al., 1992). Loor et al. (2002) have shown that cis-9 18:1, cis-9, cis-12 18:2, and cis-9, cis-12, cis-15 18:3 from dietary canola oil and soybean oil are converted primarily to 18:0 and trans-18:1 isomers in ruminal fluid as a result of PUFA biohydrogenation by rumen microbes. Cows fed SAL compared with those fed CON had higher concentrations of trans-11 18:1, trans-13+14 18:1 + cis-6+8 18:1, and cis-9 18:1. More- over, concentrations of trans-11 18:1 and cis-9 18:1 in ruminal fluid of cows fed CON were similar to those of cows fed FLA and MIX, and the concentration of trans-13+14 18:1 + cis-6+8 18:1 was lower for cows fed CON compared with those fed MIX. Concentrations of trans-9 18:1, trans-9, trans-12 18:2, cis-9, trans-11 18:2, cis-9, cis-12, cis-15 18:3, 20:0, 22:0, and 24:0 in ruminal fluid were similar among treatments. Feeding flaxseed products (FLA, SAL, and MIX diets) decreased cis-9, cis-12 18:2 FA concentration in ruminal fluid, which may result from lower cis-9, cis-12 18:2 proportions in the FLA, SAL, and MIX diets than in the CON diet (Table 1).

\section{Milk Production and Composition}

Milk production and 4\% FCM yield were similar among treatments (Table 5), in agreement with the results of Martin et al. (2008) for cows fed $12 \%$ whole flaxseed in DM compared with those fed no flaxseed. Moreover, similar milk production was reported by Chouinard et al. (1998) for cows fed a control diet 
Table 5. Milk production and milk composition of Holstein cows fed diets containing no flaxseed product (CON), whole flaxseed (FLA), calcium salts of flaxseed oil (SAL), or a mixture of whole flaxseed and calcium salts of flaxseed oil $(\mathrm{MIX})^{1}$

\begin{tabular}{lcccccc}
\hline & \multicolumn{7}{c}{ Treatment } & & \\
\cline { 2 - 5 } Item & CON & FLA & SAL & MIX & SE & $P$-value \\
\hline Milk production, kg/d & 31.5 & 32.7 & 32.6 & 32.3 & 0.5 & 0.42 \\
$\begin{array}{l}\text { 4\% FCM, kg/d } \\
\text { Milk composition, \% }\end{array}$ & 24.7 & 25.4 & 21.9 & 24.1 & 0.7 & 0.13 \\
$\quad$ Protein & 3.52 & 3.51 & 3.53 & 3.68 & 0.14 & 0.83 \\
Fat & $2.57^{\mathrm{a}}$ & $2.50^{\mathrm{ab}}$ & $1.83^{\mathrm{b}}$ & $2.30^{\mathrm{ab}}$ & 0.11 & 0.05 \\
Lactose & 4.75 & 4.80 & 4.80 & 4.80 & 0.03 & 0.54 \\
Urea N & 12.66 & 12.12 & 12.20 & 13.00 & 0.66 & 0.76 \\
$\quad$ Total solids & 11.82 & 11.78 & 11.13 & 11.75 & 0.23 & 0.29 \\
Milk yield, kg/d & & & & & & \\
Protein & 1.11 & 1.15 & 1.15 & 1.19 & 0.05 & 0.79 \\
Fat & 0.81 & 0.82 & 0.59 & 0.74 & 0.04 & 0.07 \\
Lactose & 1.50 & 1.57 & 1.56 & 1.55 & 0.02 & 0.14 \\
Total solids & 3.72 & 3.85 & 3.62 & 3.80 & 0.09 & 0.47 \\
SCS ${ }^{2}$ & 2.17 & 1.74 & 0.97 & 1.20 & 0.44 & 0.38 \\
\hline
\end{tabular}

a,b Means within a row with no common superscript differ $(P \leq 0.05)$.

${ }^{1}$ Least squares means with pooled standard error (SE).

${ }^{2} \mathrm{SCS}=\log _{10} \mathrm{SCC}$.

and those fed a diet supplemented with $4 \%$ Ca-salts of canola oil, soybean oil, or flaxseed oil.

Percentages of protein, lactose, urea N, and total solids in milk were not affected by diets (Table 5). On the other hand, milk fat concentration was lower with SAL compared with the CON diet. Similarly, feeding Ca-salts (4\% of DM) of canola oil, soybean oil, or flaxseed oil to dairy cows decreased milk fat percentage compared with a control diet (Chouinard et al., 1998). Changes in FA profile of ruminal fluid may be involved in milk fat depression. According to Shingfield and Griinari (2007), trans-10, cis-12 CLA is the only intermediate with an unequivocal inhibiting effect on milk fat synthesis, and trans-9, cis-11 CLA and cis-10, trans-12 CLA may be potential milk fat inhibitors. There was no difference in milk fat concentration between cows fed the CON diet and those fed the FLA and MIX diets or between cows fed the SAL diet and those fed the FLA and MIX diets. Similarly, Martin et al. (2008) reported no difference in milk fat concentration between cows fed $12 \%$ whole flaxseed and those fed a control diet. Milk yields of protein, fat, lactose, and total solids did not differ among treatments.

\section{Milk Fatty Acid Profile}

Proportions of short-chain FA (4:0, 5:0, 6:0, 7:0, 8:0, 9:0, 10:0, 11:0, cis-11 12:1, and 13:0) in milk fat were not affected by treatments with the exception of the proportion of 12:0, which was decreased when $1.9 \%$ Ca-salts of flax oil were added to the diet compared with CON (Table 6). Proportion of 12:0 in milk fat of cows fed SAL and MIX was similar to that of cows fed CON and FLA. Medium-chain FA (14:0, cis-9 14:1, 15:0, trans-9 16:1, and cis-9 16:1) proportions in milk fat were similar among treatments with the exception of the proportion of 16:0, which was higher $(P=0.01)$ for cows fed CON compared with cows fed flaxseed products.

The majority of 18-carbon FA in milk fat were affected by the diets, with the exception of proportions of cis-11 18:1, trans-9, trans-12 18:2, cis-9, cis-12 18:2, trans-10, cis-12 18:2, and cis-6, cis-9, cis-12 18:3, which were similar among treatments (Table 6). Moreover, concentrations of all 20- and 22-carbon FA and 24:0 were similar among treatments. Supplementation with flaxseed products tended $(P=0.07)$ to increase the proportion of 18:0 in milk fat compared with the CON diet. The proportion of trans-9 18:1 in milk fat increased when Ca-salts were added to the diets (SAL and MIX) compared with the diets without Ca-salts (CON and FLA). Cows fed SAL presented higher concentrations of trans-11 18:1 in milk fat than those fed CON and FLA, and the trans-11 18:1 concentration was similar for cows fed CON, FLA, and MIX. Feeding SAL led to the highest trans-13+14 18:1 + cis-6+8 18:1 concentration in milk fat compared with the other treatments, and the trans-13+14 18:1 + cis-6+8 18:1 concentration decreased from cows fed MIX to those fed FLA and CON (Table 6). Rumenic acid (cis-9, trans-11 18:2) proportion in milk fat was higher for cows fed SAL than for those fed FLA and it was similar between cows fed CON, MIX, and FLA. The increase in cis-9, trans-11 18:2 proportion for cows fed SAL compared with those 
Table 6. Fatty acid profile (\% of total fatty acids) in milk of Holstein cows fed diets containing no flaxseed product $(\mathrm{CON})$, whole flaxseed (FLA), calcium salts of flaxseed oil (SAL), or a mixture of whole flaxseed and calcium salts of flaxseed oil (MIX) ${ }^{1}$

\begin{tabular}{|c|c|c|c|c|c|c|}
\hline \multirow[b]{2}{*}{ Fatty acid, ${ }^{2} \%$ of total fatty acids } & \multicolumn{4}{|c|}{ Treatment } & \multirow[b]{2}{*}{ SE } & \multirow[b]{2}{*}{$P$-value } \\
\hline & $\mathrm{CON}$ & FLA & SAL & MIX & & \\
\hline 4:0 & 5.13 & 5.15 & 5.79 & 5.78 & 0.32 & 0.42 \\
\hline $5: 0$ & 0.07 & 0.07 & 0.06 & 0.06 & 0.004 & 0.19 \\
\hline $6: 0$ & 2.63 & 2.61 & 2.73 & 2.76 & 0.11 & 0.76 \\
\hline $7: 0$ & 0.12 & 0.13 & 0.08 & 0.12 & 0.02 & 0.34 \\
\hline $8: 0$ & 1.57 & 1.55 & 1.50 & 1.57 & 0.03 & 0.34 \\
\hline 9:0 & 0.14 & 0.14 & 0.10 & 0.14 & 0.02 & 0.47 \\
\hline 10:0 & 3.59 & 3.40 & 2.99 & 3.24 & 0.11 & 0.10 \\
\hline 11:0 & 0.19 & 0.17 & 0.11 & 0.15 & 0.02 & 0.25 \\
\hline $12: 0$ & $4.35^{\mathrm{a}}$ & $4.07^{\mathrm{ab}}$ & $3.37^{\mathrm{b}}$ & $3.79^{\mathrm{ab}}$ & 0.13 & 0.05 \\
\hline Cis-11 12:1 & 0.23 & 0.23 & 0.17 & 0.24 & 0.03 & 0.52 \\
\hline $13: 0$ & 0.22 & 0.20 & 0.13 & 0.17 & 0.03 & 0.26 \\
\hline $14: 0$ & 12.6 & 12.1 & 11.5 & 11.8 & 0.30 & 0.26 \\
\hline Cis-9 14:1 & 1.19 & 1.12 & 1.01 & 1.08 & 0.05 & 0.22 \\
\hline $15: 0$ & 1.49 & 1.28 & 1.03 & 1.07 & 0.13 & 0.24 \\
\hline $16: 0$ & $32.1^{\mathrm{a}}$ & $29.0^{\mathrm{b}}$ & $26.4^{\mathrm{b}}$ & $27.4^{\mathrm{b}}$ & 0.43 & 0.01 \\
\hline Trans-9 16:1 & 0.08 & 0.09 & 0.10 & 0.11 & 0.02 & 0.72 \\
\hline Cis-9 16:1 & 1.73 & 1.51 & 1.36 & 1.47 & 0.10 & 0.24 \\
\hline $17: 0$ & 0.69 & 0.66 & 0.58 & 0.65 & 0.04 & 0.43 \\
\hline $18: 0$ & 8.89 & 11.0 & 12.2 & 11.5 & 0.53 & 0.07 \\
\hline Trans-9 18:1 & $0.28^{\mathrm{b}}$ & $0.33^{\mathrm{b}}$ & $0.41^{\mathrm{a}}$ & $0.37^{\mathrm{a}}$ & 0.01 & 0.01 \\
\hline Trans-11 18:1 & $0.91^{\mathrm{b}}$ & $0.94^{\mathrm{b}}$ & $1.65^{\mathrm{a}}$ & $1.26^{\mathrm{ab}}$ & 0.08 & 0.02 \\
\hline Trans- $13+14$ 18:1 + cis- $6+8$ 18:1 & $0.73^{\mathrm{d}}$ & $1.08^{\mathrm{c}}$ & $1.98^{\mathrm{a}}$ & $1.44^{\mathrm{b}}$ & 0.04 & 0.001 \\
\hline Cis-9 18:1 & $14.8^{\mathrm{b}}$ & $16.7^{\mathrm{a}}$ & $17.6^{\mathrm{a}}$ & $16.7^{\mathrm{a}}$ & 0.14 & 0.003 \\
\hline Cis-11 18:1 & 0.68 & 0.58 & 0.56 & 0.54 & 0.04 & 0.27 \\
\hline Trans -9, trans -12 18:2 & 0.10 & 0.10 & 0.13 & 0.17 & 0.05 & 0.76 \\
\hline Cis-9, cis-12 18:2 & 2.38 & 2.31 & 2.41 & 2.30 & 0.07 & 0.68 \\
\hline Cis-9, trans-11 18:2 & $0.43^{\mathrm{ab}}$ & $0.42^{\mathrm{b}}$ & $0.67^{\mathrm{a}}$ & $0.53^{\mathrm{ab}}$ & 0.04 & 0.05 \\
\hline Trans- 10, cis-12 18:2 & 0.02 & 0.01 & 0.02 & 0.02 & 0.01 & 0.69 \\
\hline Cis-6, cis-9, cis-12 18:3 & 0.07 & 0.07 & 0.06 & 0.08 & 0.01 & 0.65 \\
\hline Cis-9, cis- 12, cis-15 18:3 & $0.59^{\mathrm{b}}$ & $0.84^{\mathrm{ab}}$ & $1.03^{\mathrm{a}}$ & $0.95^{\mathrm{a}}$ & 0.05 & 0.02 \\
\hline 19:0 & $0.21^{\mathrm{c}}$ & $0.30^{\mathrm{bc}}$ & $0.51^{\mathrm{a}}$ & $0.40^{\mathrm{ab}}$ & 0.02 & 0.01 \\
\hline Cis-7 19:1 & 0.09 & 0.05 & 0.09 & 0.09 & 0.02 & 0.51 \\
\hline 20:0 & 0.30 & 0.27 & 0.32 & 0.35 & 0.05 & 0.74 \\
\hline Cis-8 20:1 & 0.20 & 0.28 & 0.20 & 0.25 & 0.03 & 0.70 \\
\hline Cis-11 20:1 & 0.13 & 0.14 & 0.13 & 0.17 & 0.03 & 0.71 \\
\hline Cis-11, cis-14 20:2 & 0.13 & 0.15 & 0.13 & 0.18 & 0.03 & 0.63 \\
\hline Cis-8, cis-11, cis-14 20:3 & 0.18 & 0.18 & 0.15 & 0.18 & 0.01 & 0.40 \\
\hline Cis-5, cis-8, cis-11, cis-14 20:4 & 0.22 & 0.20 & 0.17 & 0.20 & 0.01 & 0.22 \\
\hline Cis-5, cis-8, cis-11, cis- 14, cis-17 20:5 & 0.10 & 0.10 & 0.10 & 0.12 & 0.02 & 0.71 \\
\hline $22: 0$ & 0.12 & 0.14 & 0.12 & 0.15 & 0.01 & 0.31 \\
\hline $22: 4$ & 0.10 & 0.09 & 0.07 & 0.08 & 0.01 & 0.48 \\
\hline $22: 5$ & 0.20 & 0.22 & 0.20 & 0.25 & 0.03 & 0.68 \\
\hline 24:0 & 0.10 & 0.06 & 0.10 & 0.12 & 0.03 & 0.78 \\
\hline Total trans & $1.83^{\mathrm{b}}$ & $1.89^{\mathrm{ab}}$ & $2.97^{\mathrm{a}}$ & $2.45^{\mathrm{a}}$ & 0.17 & 0.05 \\
\hline Unknown & 7.68 & 8.04 & 10.8 & 10.7 & 1.16 & 0.28 \\
\hline MUFA & $21.1^{\mathrm{c}}$ & $23.0^{\mathrm{bc}}$ & $25.3^{\mathrm{ab}}$ & $23.7^{\mathrm{ab}}$ & 0.38 & 0.02 \\
\hline PUFA & 4.52 & 4.69 & 5.19 & 5.05 & 0.29 & 0.45 \\
\hline SFA & $74.4^{\mathrm{a}}$ & $72.3^{\mathrm{ab}}$ & $69.6^{\mathrm{b}}$ & $71.3^{\mathrm{ab}}$ & 0.66 & 0.05 \\
\hline PUFA/SFA & 0.06 & 0.06 & 0.07 & 0.07 & 0.004 & 0.31 \\
\hline SCFA & 18.3 & 17.7 & 17.0 & 18.0 & 0.36 & 0.28 \\
\hline MCFA & $49.1^{\mathrm{a}}$ & $45.1^{\mathrm{ab}}$ & $41.3^{\mathrm{b}}$ & $43.0^{\mathrm{b}}$ & 0.62 & 0.001 \\
\hline LCFA & $31.9^{\mathrm{c}}$ & $36.5^{\mathrm{b}}$ & $41.1^{\mathrm{a}}$ & $38.4^{\mathrm{b}}$ & 0.37 & 0.002 \\
\hline $\mathrm{n}-3^{3}$ & 0.88 & 1.16 & 1.39 & 1.32 & 0.08 & 0.07 \\
\hline$n-6^{4}$ & 3.09 & 3.00 & 3.00 & 3.01 & 0.13 & 0.95 \\
\hline n-6:n-3 & $3.48^{\mathrm{a}}$ & $2.61^{\mathrm{b}}$ & $2.19^{\mathrm{b}}$ & $2.27^{\mathrm{b}}$ & 0.10 & 0.01 \\
\hline
\end{tabular}


fed FLA disagrees with the results of Brzóska (2006), who reported similar proportions for cows fed from 0 to $5.4 \%$ Ca-salts of flaxseed oil in the DM. Differences between experiments could result in a different level of protection against ruminal biohydrogenation between Ca-salts used in the present experiment and those used by Brzóska (2006). Feeding SAL increased intermediates of ruminal biohydrogenation (trans-9 18:1, trans-11 18:1, and trans-13+14 18:1 + cis-6+8 18:1) and proportions of cis-9, trans-11 18:2 in milk fat compared with feeding FLA, which may suggest that the Ca-salts of flaxseed oil fed in the present experiment were not totally protected in the rumen. This result is consistent with the partial protection of Ca-salts of FA against ruminal biohydrogenation reported by Ferlay et al. (1992). Similarly, higher concentrations of trans-9 and trans-11 18:1 were observed in milk fat of cows fed 3 different Ca-salts from canola oil, flaxseed oil, and soybean oil compared with cows fed a control diet (Chouinard et al., 1998). According to $\mathrm{Wu}$ and Palmquist (1991), 58\% of 18-carbon FA in Ca-salts are biohydrogenated in vitro. Moreover, Castañeda-Gutiérrez et al. (2007) reported that milk fat concentrations of eicosapentaenoic acid and docosahexaenoic acid were 5 to 6 times greater when fish oil was infused in the abomasum compared with when Ca-salts of fish oil were infused in the rumen, resulting in more than $85 \%$ of eicosapentaenoic acid and $75 \%$ of docosahexaenoic acid of fish oil in the form of Ca-salts being biohydrogenated in the rumen.

In the present experiment, greater concentrations of biohydrogenation intermediates of FA in milk fat of cows fed the SAL and MIX diets compared with the FLA diet suggest that biohydrogenation of PUFA was likely less complete when flaxseed oil was fed as Ca-salts than when fed as whole seed. A similar conclusion may be drawn from the experiment of Chilliard et al. (2009) who reported that although the formation of trans FA was more important with extruded than with whole flaxseed because of a rapid oil release, more cis-9, cis12, cis-15 18:3 might have been protected from ruminal biohydrogenation with extruded than with whole flaxseed. The concentration of cis-9, cis-12, cis-15 18:3 in milk fat was higher for treatments with Ca-salts (SAL and MIX) compared with the control diet. Similarly, a linear increase in cis-9, cis-12, cis-15 18:3 concentration of milk fat has been reported with increased levels of Ca-salts of flaxseed oil in the diet $(0,1.84,3.54$, and $5.40 \%$ of the DM; Brzóska, 2006). Moreover, higher concentrations of cis-9, cis-12, cis-15 18:3 have been observed in milk fat of cows fed ground compared with whole flaxseed at $12 \%$ of DM (Da Silva et al., 2007), which may suggest that flaxseed processing is required to increase the proportion of cis-9, cis-12, cis-15 18:3 in milk fat. This agrees with the results of Chilliard et al. (2009) who reported that feeding $14.8 \%$ extruded flaxseed compared with $12.4 \%$ whole flaxseed increased the proportion of cis-9, cis-12, cis-15 18:3 in milk fat, which may result from a rapid release of oil from extruded seeds. As proportions of cis-9, cis-12, cis-15 18:3 FA did not differ in milk fat of cows fed Ca-salts of flaxseed oil (SAL) and in milk fat of those fed a mixture of Ca-salts of flaxseed oil and whole flaxseed (MIX), this may imply that both diets similarly enhanced FA profile of milk fat. Contrary to our hypothesis that a mixture of unprotected (e.g., whole flaxseed) and partially protected (Ca-salts of flaxseed oil) n-3 FA would result in the best milk FA profile for human health, there was no advantage to feeding MIX compared with SAL to increase the proportions of n-3 FA and cis-9, trans-11 18:2 in milk fat. However, the small number of cows and the small increase in diet ether extract content due to lipid supplementation (1.4 and $0.7 \%$ for FLA and SAL, respectively) could have contributed to the lack of differences in milk FA profiles among diets.

Supplementing diets with Ca-salts of flaxseed oil (SAL and MIX) significantly increased concentrations of total trans FA and monounsaturated FA in milk fat compared with CON, and there was no difference between cows fed FLA and those fed the other 3 diets (Table 6). The concentration of saturated FA in the milk fat of cows fed SAL was lower than in that of cows fed CON, and there was no difference between cows fed SAL and those fed FLA and MIX (Table 6). Adding Ca-salts to the diet (SAL and MIX) decreased the concentration of medium-chain FA in milk fat compared with CON. Moreover, there was no difference in medium-chain FA concentration between CON and FLA and among FLA, SAL, and MIX diets. Cows fed CON and SAL had, respectively, the lowest and highest longchain FA concentrations, whereas cows supplemented with whole flaxseed in the diet (FLA and MIX) had intermediate and similar long-chain FA concentrations in milk fat. The concentration of n-3 FA tended $(P=$ 0.07 ) to differ among diets. Concentrations of n-3 FA were numerically higher for cows fed the SAL and MIX diets compared with those fed the CON and FLA diets. The n-6 to n-3 FA ratio in milk fat was significantly lower for cows fed flaxseed products (FLA, SAL, and MIX) compared with those fed CON.

\section{CONCLUSIONS}

Whole flaxseed and Ca-salts of flaxseed oil supplying 0.7 to $1.4 \%$ of fat $(4.2 \%$ of whole flaxseed, $1.9 \%$ of Casalts of flax oil, or $2.3 \%$ of flaxseed whole $+0.8 \%$ calcium salts of flaxseed oil) in the diets of dairy cows had no effect on feed intake, apparent digestibility of DM, or milk production. Calcium salts of flaxseed oil fed at 
$1.9 \%$ of DM decreased milk fat concentration compared with a control diet, whereas concentrations of protein, lactose, urea $\mathrm{N}$, and total solids in milk were not affected. Calcium salts of flaxseed oil fed at 0.8 and $1.9 \%$ of the dietary DM increased concentrations of rumenic acid and intermediates of biohydrogenation (trans-9 18:1) in milk fat compared with whole flaxseed and increased $\alpha$-linolenic acid concentration compared with a control diet. Milk fat concentration of $\alpha$-linolenic acid was increased by feeding $1.9 \%$ Ca-salts of flaxseed oil and a mixture of $0.8 \%$ Ca-salts of flaxseed oil and $2.3 \%$ whole flaxseed compared with feeding a control diet. However, all diets supplemented with flaxseed products had similar concentrations of $\alpha$-linolenic acid in milk fat. All flaxseed products (whole flaxseed and Ca-salts) decreased the n- 6 to n- 3 fatty acid ratio in milk fat. Results confirm that flax products supplemented at 1.5\% of fat in the diet could slightly improve the nutritive value of milk fat.

\section{ACKNOWLEDGMENTS}

D.C.S.K. and R.K. were recipients of a studentship and G.T.D.S. and L.M.Z. were recipients of a fellowship from Conselho Nacional de Desenvolvimento Científico e Tecnológico and Fundação Araucária do Paraná (Brazil). C.C. was a recipient of a fellowship from the National Science and Engineering Research Council of Canada. The present study was funded by Agriculture and Agri-Food Canada (Sherbrooke, QC, Canada). The authors express their gratitude to the staff of the Dairy and Swine Research \& Development Centre (Sherbrooke, QC, Canada) for their contribution to the present study. We especially want to thank Véronique Roy and Liette Veilleux for technical assistance and Steve Méthot for his help in the statistical analyses. The gracious donation of calcium salts by Virtus Nutrition (Corcoran, CA) was greatly appreciated.

\section{REFERENCES}

Allen, M. S. 2000. Effects of diet on short-term regulation of feed intake by lactating dairy cattle. J. Dairy Sci. 83:1598-1624.

AOAC. 1990. Official Methods of Analysis. 15th ed. AOAC, Washington, DC.

Belury, M. A. 2002. Dietary conjugated linoleic acid in health Physiological effects and mechanisms of action. Annu. Rev. Nutr. $22: 505-531$.

Brzóska, F. 2006. Effect of fatty acid calcium salts from linseed oil on yield and n-3 fatty acid content of milk and on blood plasma parameters of cows. J. Anim. Feed Sci. 15:347-360.

Canadian Council on Animal Care. 1993. Guide to the Care and Use of Experimental Animals. Vol. 1. E. D. Offert, B. M. Cross, and A. A. McWilliam, ed. CCAC, Ottawa, ON, Canada.

Castañeda-Gutiérrez, E., M. J. de Veth, A. L. Lock, D. A. Dwyer, K. D. Murphy, and D. E. Bauman. 2007. Effect of supplementation with calcium salts of fish oil on n-3 fatty acids in milk fat. J. Dairy Sci. 90:4149-4156.

Chalupa, W., B. Vecchiarelli, A. E. Elser, D. S. Kronfeld, D. Sklan, and D. L. Palmquist. 1986. Ruminal fermentation in vivo as influenced by long chain fatty acids. J. Dairy Sci. 69:1293-1301.

Chilliard, Y., C. Martin, J. Ruel, and M. Doreau. 2009. Milk fatty acids in dairy cows fed whole crude linseed, extruded linseed, or linseed oil, and their relationship with methane output. J. Dairy Sci. 92:5199-5211.

Chouinard, P. Y., V. Girard, and G. J. Brisson. 1998. Fatty acid profile and physical properties of milk fat from cows fed calcium salts of fatty acids with varying unsaturation. J. Dairy Sci. 81:471-481.

Chouinard, P. Y., J. Lévesque, V. Girard, and G. J. Brisson. 1997. Dietary soybeans extruded at different temperatures: Milk composition and in situ fatty acid reactions. J. Dairy Sci 80:2913-2924.

da Silva, D. C., G. T. Santos, A. F. Branco, J. C. Damasceno, R. Kazama, M. Masushita, J. A. Horst, W. B. R. Dos Santos, and H. V. Petit. 2007. Production performance and milk composition of dairy cows fed whole or ground flaxseed with or without monensin. J. Dairy Sci. 90:2928-2936.

Doreau, M., E. Aurousseau, and C. Martin. 2009. Effects of linseed lipids fed as rolled seeds, extruded seeds or oil on organic matter and crude protein digestion in cows. Anim. Feed Sci. Technol 150:187-196.

Edmonson, A. J., I. J. Lean, L. D. Weaver, T. Farver, and G. Webster 1989. A body condition scoring chart for Holstein for dairy cows. J. Dairy Sci. 72:68-78.

Enjalbert, F., M. C. Nicot, C. Bayourthe, M. Vernay, and R. Moncoulon 1997. Effects of dietary calcium soaps of unsaturated fatty acids on digestion, milk composition and physical properties of butter. J. Dairy Res. 64:181-195.

Ferlay, A., Y. Chilliard, and M. Doreau. 1992. Effect of calcium salts differing in fatty acids composition on duodenal and milk fatty acids profiles in dairy cows. J. Sci. Food Agric. 60:31-37.

Glasser, F., A. Ferlay, and Y. Chilliard. 2008. Oilseed lipid supplements and fatty acid composition of cow milk: a meta-analysis. J. Dairy Sci. 91:4687-4703.

Gonthier, C., A. F. Mustafa, R. Berthiaume, H. V. Petit, R. Martineau, and D. R. Ouellet. 2004. Effects of feeding micronized and extruded flaxseed on ruminal fermentation and nutrient utilization by dairy cows. J. Dairy Sci. 87:1854-1863.

Harvatine, K. J., and M. S. Allen. 2005. The effect of production level on feed intake, milk yield and endocrine response to two fatty acid supplements in lactating cows. J. Dairy Sci. 88:4018-4027.

Loor, J. J., A. B. P. A. Bandara, and J. H. Herbein. 2002. Characterization of 18:1 and 18:2 isomers produced during microbial biohydrogenation of unsaturated fatty acids from canola and soybean oil in the rumen of lactating cows. J. Anim. Physiol. A Anim. Nutr. 86:422-434.

Maia, M. R. G., L. C. Chaudhary, L. Figueres, and R. J. Wallace. 2007. Metabolism of polyunsaturated fatty acids and their toxicity to the microflora of the rumen. Antonie van Leeuwenhoek 91:303-314.

Martin, C., J. Rouel, J. P. Jouany, M. Doreau, and Y. Chilliard. 2008 Methane output and diet digestibility in response to feeding dairy cows crude linseed, extruded linseed, or linseed oil. J. Anim. Sci. $86: 2642-2650$.

Mustafa, A. F., J. J. McKinnon, D. A. Christensen, and T. He. 2002 Effects of micronization of flaxseed on nutrient disappearance in the gastrointestinal tract of steers. Anim. Feed Sci. Technol. 95:123-132.

Novozamsky, I., R. Van Eck, J. C. Van Schouwenburg, and I. Walinga. 1974. Total nitrogen determination in plant material by means of the indophenol-blue method. Neth. J. Agric. Sci. 22:3-5.

NRC. 2001. Nutrient Requirements of Dairy Cattle. 7th rev. ed. Nat. Acad. Press, Washington, DC.

Park, P. W., and R. E. Goins. 1994. In situ preparation of fatty acid methyl esters for analysis of fatty acid composition in foods. J. Food Sci. 59:1262-1266. 
Petit, H. V. 2002. Digestion, milk production, milk composition, and blood composition of dairy cows fed whole flaxseed. J. Dairy Sci. 85:1482-1490.

Petit, H. V., R. J. Dewhurst, N. D. Scollan, J. G. Proulx, M. Khalid, W. Haresign, H. Twagiramungu, and G. E. Mann. 2002. Milk production and composition, ovarian function, and prostaglandin secretion of dairy cows fed omega-3 fats. J. Dairy Sci. 85:889899.

Precht, D., J. Molkentin, M. A. McGuire, M. K. McGuire, and R. G. Jensen. 2001. Overestimates of oleic and linoleic acid contents in materials containing trans fatty acids and analyzed with short packed gas chromatographic columns. Lipids 36:213-216.

SAS Institute. 2000. SAS software User's Guide. Release 8.02. SAS Inst., Inc., Cary, NC.

Secchiari, P., M. Antongiovanni, M. Mele, A. Serra, A. Buccioni, G. Ferruzzi, F. Paoletti, and F. Petacchi. 2003. Effect of kind of dietary fat on the quality of milk fat from Italian Friesian cows. Livest. Prod. Sci. 83:43-52.

Shingfield, K. J., and J. M. Griinari. 2007. Role of biohydrogenation intermediates in milk fat depression. Eur. J. Lipid Sci. Technol. 109:799-816.
Sukhija, P. S., and D. L. Palmquist. 1988. Rapid method for determination of total fatty acid content and composition of feedstuffs and feces. J. Agric. Food Chem. 36:1202-1206.

Sukhija, P. S., and D. L. Palmquist. 1990. Dissociation of calcium soaps of long-chain fatty acids in rumen fluid. J. Dairy Sci. 73:1784-1787.

Tyrrell, H. F., and J. T. Reid. 1965. Prediction of the energy value of cow's milk. J. Dairy Sci. 48:1215-1223.

Van Soest, P. J., J. B. Robertson, and B. A. Lewis. 1991. Methods for dietary fiber, neutral detergent fiber, and nonstarch polysaccharides in relation to animal nutrition. J. Dairy Sci. 74:3583-3597.

Wright, T., B. McBride, and B. Holub. 1998. Docosahexaenoic acidenriched milk. World Rev. Nutr. Diet. 83:160-165.

Wu, Z., and D. L. Palmquist. 1991. Synthesis and biohydrogenation of fatty acids by ruminal microorganisms in vitro. J. Dairy Sci. 74:3035-3046. 